Bull. Mater. Sci., Vol. 8, No. 4, October 1986, pp. 471-478.

(C) Printed in India.

\title{
Emission spectrographic technique for the quantitative determination of trace elements in granitic rocks
}

\author{
A EL BIALY, M RASMY*, L A GUIRGUIS** and W MOUSSA \\ Women's College, Ain Shams University, Cairo, Egypt \\ * Earth Sciences Laboratories, National Research Centre, Cairo, Egypt \\ ** Nuclear Materials Corporation, Cairo, Egypt
}

MS received 14 March 1985; revised 29 July 1985

\begin{abstract}
An emission spectrographic technique was developed to estimate 16 trace elements in some samples of Egyptian granite. The detection limits were: $0.1 \mathrm{ppm}$ for $\mathrm{Pb}, \mathrm{Ba}, \mathrm{Mo}, \mathrm{Cu}$, $\mathrm{Cr}, \mathrm{Yb}$ and $\mathrm{Ni}, 0.3 \mathrm{ppm}$ for $\mathrm{Sn}, \mathrm{Ga}$ and $\mathrm{Be}, 1 \mathrm{ppm}$ for $\mathrm{Co}, \mathrm{Sc}$ and $\mathrm{V}, 3 \mathrm{ppm}$ for $\mathrm{Bi}$ and $\mathrm{Y}$ and $10 \mathrm{ppm}$ for $\mathrm{La}$. The relative deviation of the two-thirds limits ranges between $\pm 1 \cdot 5$ and $\pm 24 \cdot 7$.
\end{abstract}

Keywords. Emission spectrography; granitic rocks; trace elements.

\section{Introduction}

Crystalline rocks, including igneous and metamorphic types, constitute more than $95 \%$ of the earth's crust. Granites are the most common igneous rocks. Many valuable ore deposits are genetically related to granitic rocks. Therefore, the determination of trace elements in granite is essential for both genetic and economic reasons. The technique of spectrographic analysis of granites has drawn the attention of a great number of authors (Ahrens and Taylor 1961; Sighinolfi 1966; Peter 1969; Fleischer 1972; Gokun 1975; Watson and Russell 1978). Granites are coarse-grained acid igneous rocks which are mainly composed of alkali feldspars, acid plagioclasses, mica and some other accessory minerals. Granites contain high $\mathrm{SiO}_{2}$ content (usually above $65 \%$ ) and are therefore considered acidic and responsible for the dense silica bands in spectrographic analysis. Besides, the increased ratio of alkalies perceptibly lowers the arc temperature. These factors give rise to a dense background and low sensitivity of the analysed elements.

The aim of the present work is to develop a specific technique by which arcing conditions of granite are improved and sensitivities of the elements increased.

\section{Experimental}

The emission spectrographic technique was developed to determine 16 trace elements in some samples of Egyptian granite using a Zeiss Jena grating spectrograph. Graphite was used as a buffering material while $\mathrm{CdF}_{2}$ was added as a carrier. The current intensity was $1.4 \mathrm{~A}$, time was $50 \mathrm{sec}$ and $\mathrm{Pd}$ was used as the internal standard for most elements.

The optimum conditions of spectrographic analysis of granite can be achieved by studying some factors. These are discussed in this paper. 


\subsection{Electrode type}

For practical reasons, only rod-type graphite electrodes were experimented. Four forms of each of the sample and counter electrodes were alternatively tested. These forms are similar to the Ringsdroff types (RW0006, RW0021, RW0068, RW0070, RW0083, RW0028 and RW0067) with tip angles $20^{\circ}$ and $30^{\circ}$. The best forms that gave good burning conditions and high line intensities are those similar to the sample form RW0021 and counter form RW0028. The electrodes (electrode gap: $3.5 \mathrm{~mm}$ ) were shaped from JMC specpure graphite rods. These are shown in figure 1 and are given the
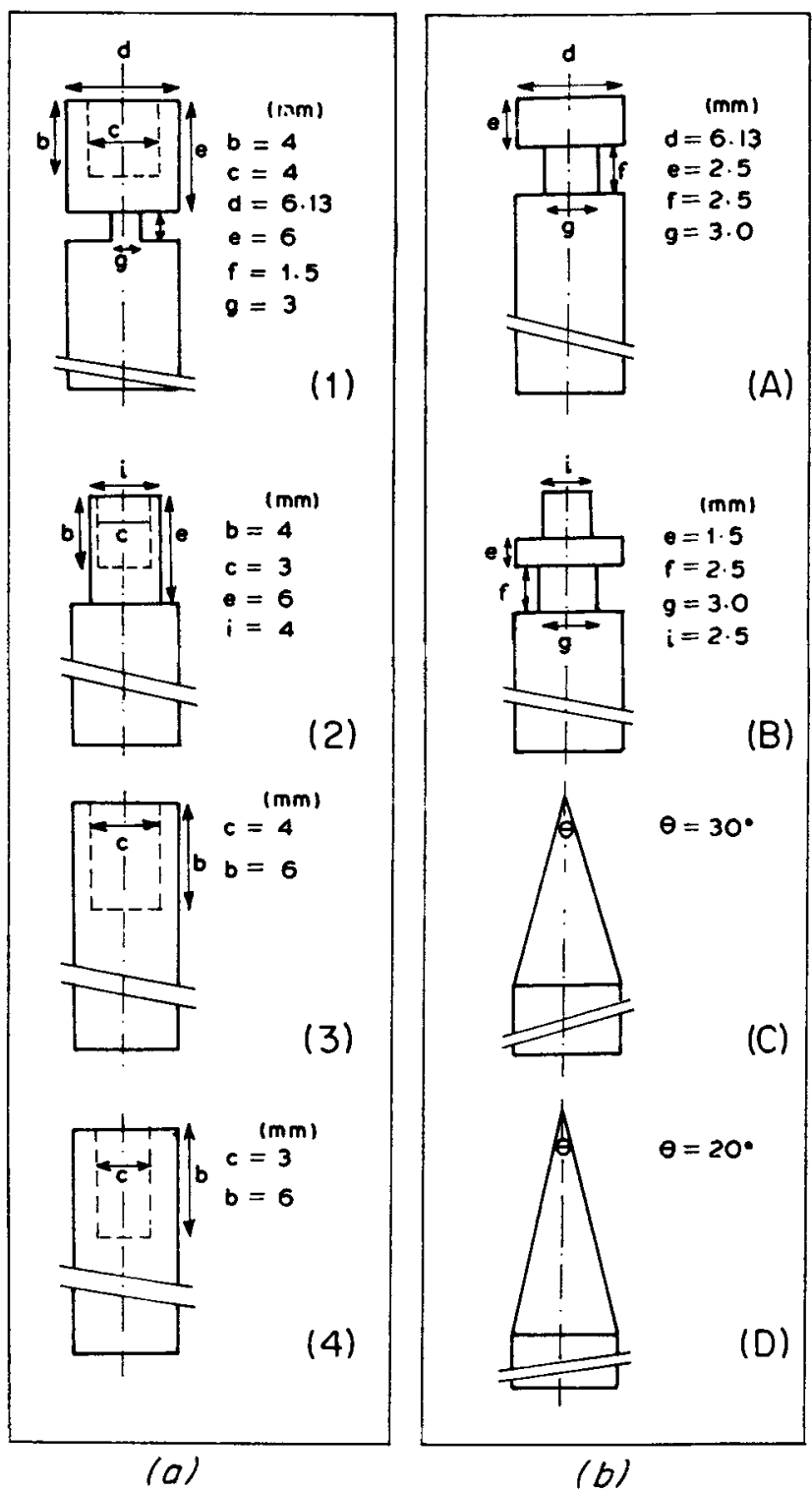

Figure 1. Electrode shape. 
symbols 1, 2, 3 and 4 for sample electrodes (anode) and A, B, C and D for counter electrodes (cathode) respectively.

\subsection{Current intensity}

According to Bowmans (1966) the intensities of the spectral lines are influenced by the arc current. It is important to obtain the best current intensity to have a smooth burning arc and a stable arc spot.

The dependence of the current densities of the test lines: Ba: $455.404 \mathrm{~nm}$, Ti: $337.280 \mathrm{~nm}$, Cr: $425.434 \mathrm{~nm}, \mathrm{Zr}: 339.198 \mathrm{~nm}, \mathrm{Zn:} 328.233 \mathrm{~nm}, \mathrm{~V}: 437.924 \mathrm{~nm}$, Pb: $283.307 \mathrm{~nm}$, Mo: $317.035 \mathrm{~nm}$, Be: $213.042 \mathrm{~nm}, \mathrm{Yb}: 328.937 \mathrm{~nm}$ and $\mathrm{Y}: 332.788 \mathrm{~nm}$ on the arc current from 6 to $15 \mathrm{~A}$ is represented graphically in figure 2 . It is clear that the line densities increase gradually with current intensity. Moreover some of the rare earth elements such as $\mathrm{Y}$ and $\mathrm{Yb}$ did not appear except at a high current intensity (12 A). The best practical current intensity was $14 \mathrm{~A}$.

\subsection{Buffers and carriers}

A wide range of additives was used. They include graphite powder, alkali and alkaline earth carbonates and halides, oxides of $\mathrm{Mg}, \mathrm{Zn}, \mathrm{Zr}$ and $\mathrm{Ga}$ as well as heavy metal halides (Rasmy 1983) in varying ratios. It was observed that the best buffer and carrier are graphite powder and cadmium fluoride respectively. The ideal mixing ratio of sample, graphite and $\mathrm{CdF}_{2}$ is $2: 2: 1$. Figure 3 shows a moving plate study at $10 \mathrm{sec}$ intervals for three cases, from which the following can be concluded:

(a) When the sample is arced alone, the distillation period exceeds $160 \mathrm{sec}$ till the nonvolatile elements, e.g. $Y$, attain their peaks.

(b) When a mixture of equal amounts of the sample and graphite powder is arced, the distillation period is rather shortened and arcing is improved. However, some elements like $Y$ and Mo exhibit double peaks.

(c) When the ideal mixture of the sample, graphite and $\mathrm{CdF}_{2}$ is arced, the distillation period is greatly shortened. Each element exhibits one peak and all peaks appear during the first 50 seconds of arcing. Besides, densities of spectral lines of the elements are perceptibly increased. It seems that the most suitable exposure time is $50 \mathrm{sec}$, by which time a reasonable background intensity is developed.

\subsection{Sample preparation}

Samples of granite, each about $2 \mathrm{~kg}$, were crushed by hammering. Small representative samples were prepared by quartering method and ground to about 200 mesh using an agate mortar. Contamination was always avoided.

\subsection{Synthetic standards}

A matrix was prepared, the composition of which is close to the average composition of granite given by Wedepohl (1969). The small content of $\mathrm{Mn}, \mathrm{Ti}$ and $\mathrm{P}$ oxides was excluded as $\mathrm{P}_{2} \mathrm{O}_{5}$ was not provided as a specpure chemical while $\mathrm{Mn}$ and $\mathrm{Ti}$ are later added as a part of the trace elements to be analysed. After thorough mixing of the matrix components, they were sintered in a platinum dish at $1200^{\circ} \mathrm{C}$ for $6 \mathrm{hr}$, cooled and ground to 200 mesh. The final composition of the matrix was expected to be: 


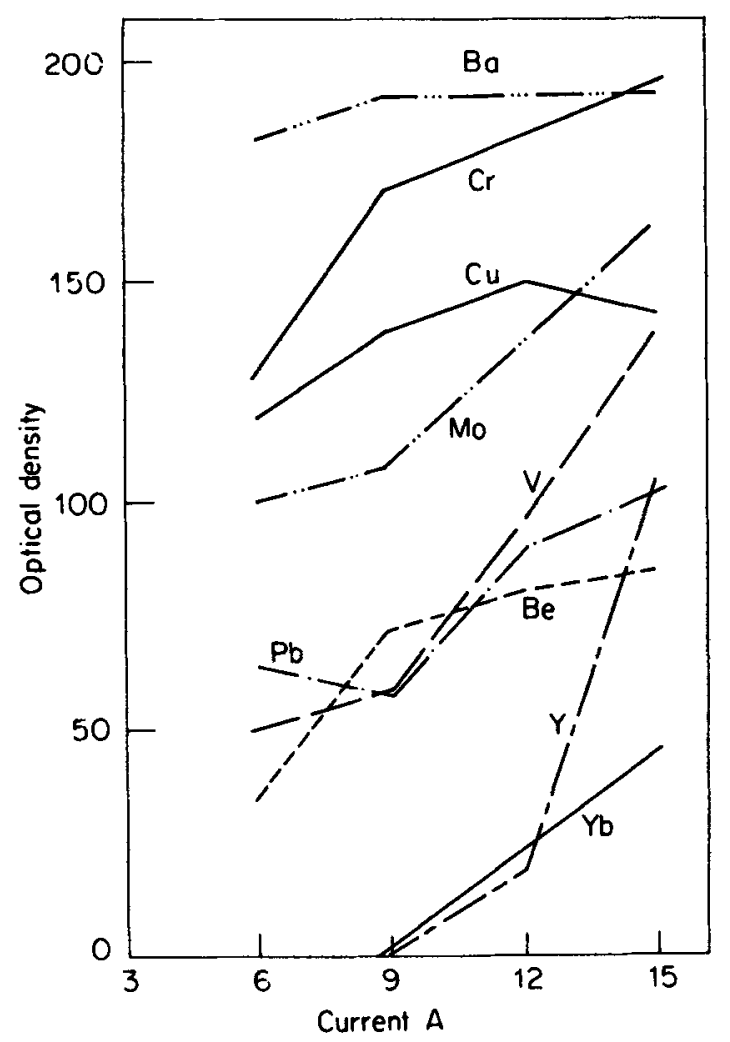

Figure 2. Current effect.

$72.91 \% \mathrm{SiO}_{2}, 14.02 \% \mathrm{Al}_{2} \mathrm{O}_{3}, 2.56 \% \mathrm{Fe}_{2} \mathrm{O}_{3}, 0.53 \% \mathrm{MgO}, 1.35 \% \mathrm{CaO}, 3 \cdot 12 \% \mathrm{Na}_{2} \mathrm{O}$ and $5.52 \% \mathrm{~K}_{2} \mathrm{O}$.

The first standard, containing $3000 \mathrm{ppm}$ of each of the trace ingradients, was prepared from the calculated amount of JMC Spectromel No. 1 mixture containing $1.18 \%$ of 53 different trace elements, to which the corresponding amounts of the oxides of $\mathrm{Y}, \mathrm{La}$ and $\mathrm{Yb}$ are added and finally diluted with the weighed amount of the matrix. From this first standard, other standards containing $1000,300,100 \ldots$ down to $0.1 \mathrm{ppm}$ of the trace elements were prepared by successive dilution with the matrix.

\subsection{Internal standard}

An amount equivalent to $100 \mathrm{ppm}$ palladium, as chloride, was added to each of the samples and standards for internal standardization. The intensities of the less volatile elements (Ahrens and Taylor 1961) are related to that of Pd. No other internal standard could be used for volatile elements including $\mathrm{Ga}, \mathrm{Pb}, \mathrm{Cu}$ and $\mathrm{Sn}$. They were related to their adjacent background. 

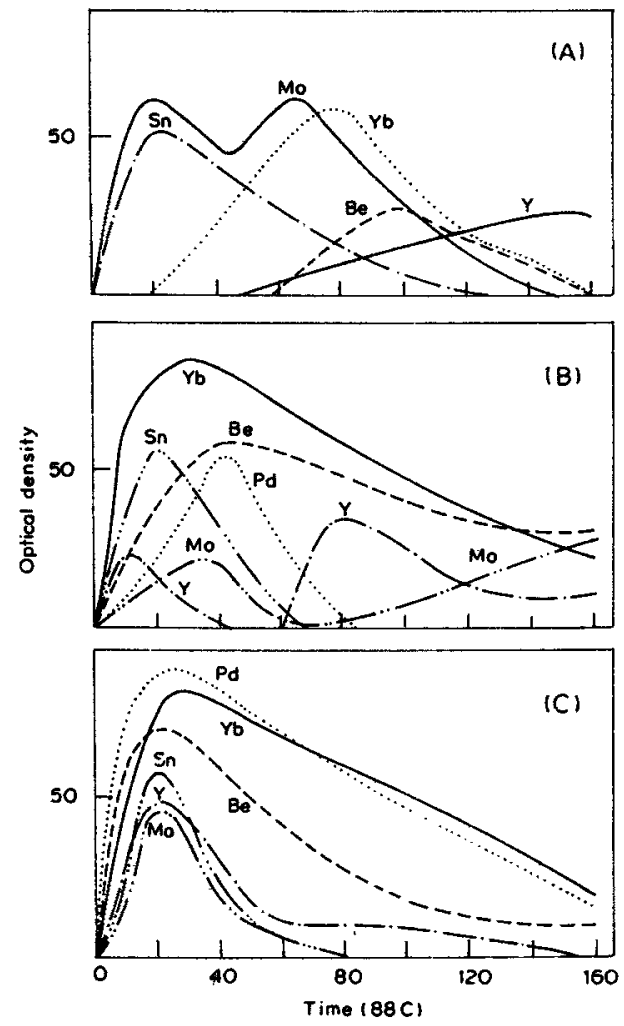

Figure 3. Time-intensity diagrams of granite standard with about $100 \mathrm{ppm}$ traces showing the effect of buffer and carrier: (A) Standard alone, (B) Standard: Buffer 1/1, (C) Standard: Buffer: $\mathrm{CdF}_{2}$ 2/2/1.

\subsection{Slit width adjustments}

The slit width of the spectrograph is of great importance when the background effect is considered. The background intensity, due to continuous radiation, increases with slit width. Therefore the slit must be adjusted to give maximum line intensity with reasonable background. The granitic sample was arced using variable values of slit width such as $10,12,14$ and $16 \mu$. It is clear from the results obtained (figure 4 ) that the slit width of $12 \mu$ was most preferable, considering the exposure time of $50 \mathrm{sec}$ and other conditions.

\subsection{Calibration and evaluation}

Calibration curves were drawn by plotting blackness $D$ of some $F e$ spectral lines against their $\log$ intensities using a six-step diminisher with $100,40,16,10,6$ and $4 \%$ transmissions. Four curves were drawn covering the whole wavelength range 282-456 nm (figure 5). The background correction was made using the relation given by Mika and Torok (1974). 


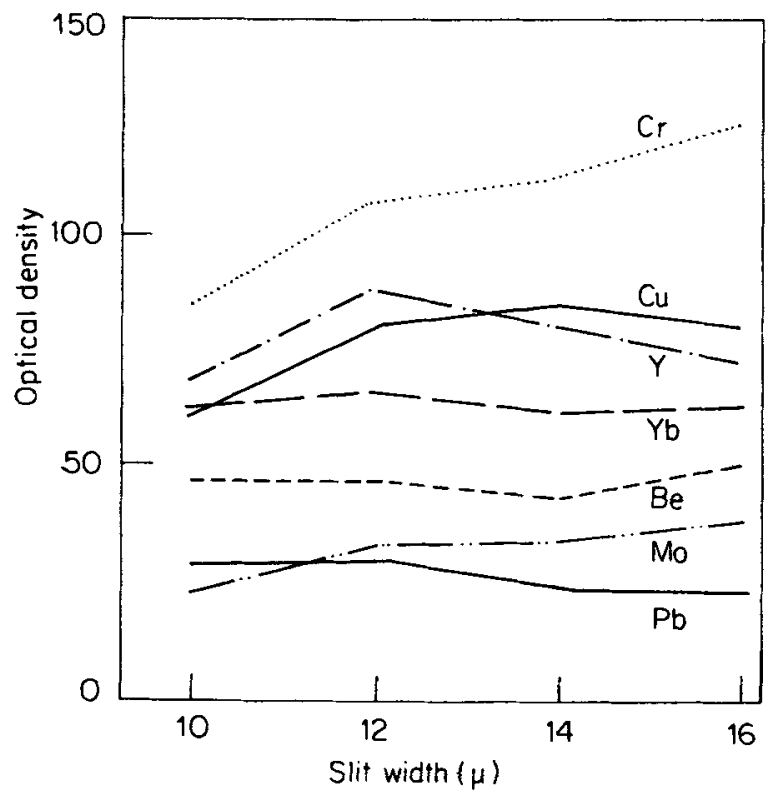

Figure 4. Effect of slit width.

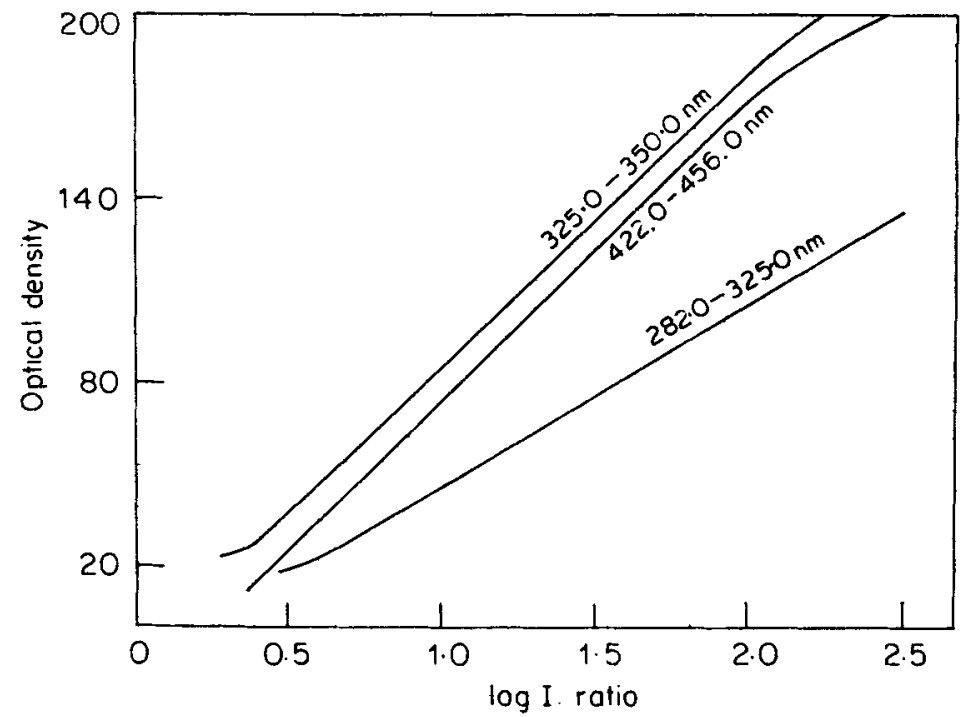

Figure 5. Sample of the calibration curves.

Working curves were drawn between log intensity ratio and log concentration (figure 6). The trace elements content of the analyzed granite samples and its implications were discussed in detail by El Bialy et al (1984). The analytical lines and detection limits of the analysed elements of our work and that of Gokun (1975) (the best available compatible work) are shown in table 1. 
Table 1 shows that the improvements in the minimum detection limit are as follows: 1000 for $\mathrm{Pb}, \mathrm{Mo}, \mathrm{Cu}, \mathrm{Yb}, \mathrm{Ni}, \mathrm{Cr}$ and $\mathrm{Ba}, 333.33$ for $\mathrm{Ga}$ and $\mathrm{Be}, 100$ for $\mathrm{Co}$, Sc and $\mathrm{V}$, 33.33 for $Y$ and 16.66 for Sn.

\subsection{Precision and accuracy}

Precision expressed as the standard deviation $S$ and the relative deviation $C$ at the twothirds limits is shown in table 2 using data obtained by arcing granite rock standard $G_{2}$, distributed by the U.S. Geological survey, as an unknown sample. The standard deviation $S$ ranges between \pm 0.02 and \pm 1.9 ppm while the relative deviation $C$ ranges

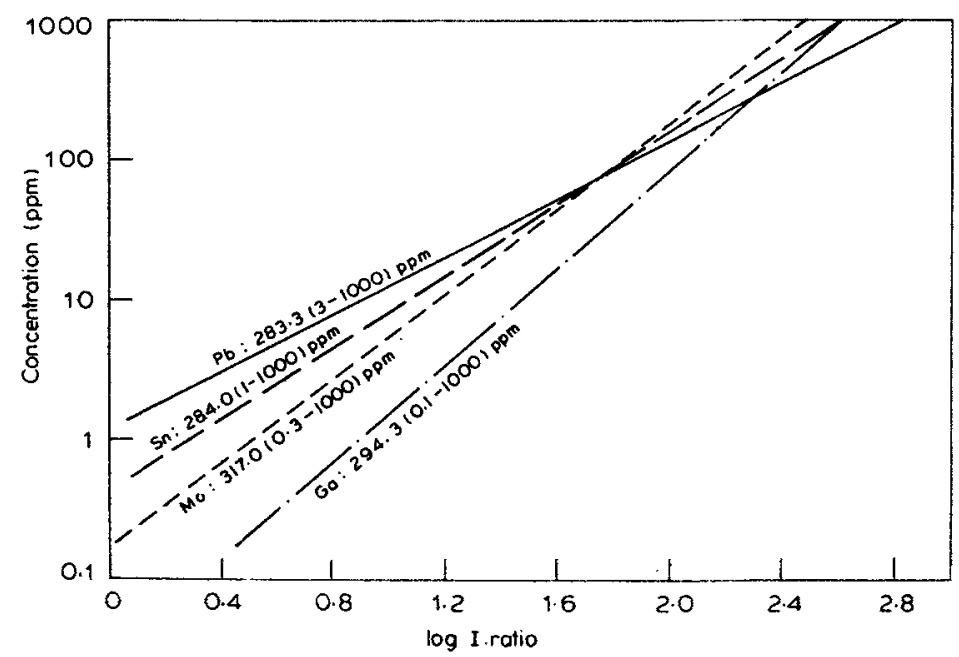

Figure 6. Samples of working curves for the determination of $\mathrm{Pb}, \mathrm{Sn}, \mathrm{Mo}$ and $\mathrm{Ga}$.

Table 1. Detection limits and wavelength of spectral lines of the analysed elements of the present work compared to that of Gokun (1975)

\begin{tabular}{|c|c|c|c|c|c|c|c|}
\hline \multirow[b]{2}{*}{ Element } & \multirow{2}{*}{$\begin{array}{c}\text { Wave- } \\
\text { length } \\
\text { (nm) }\end{array}$} & \multicolumn{2}{|c|}{$\begin{array}{l}\text { Detection limit } \\
\text { (ppm) }\end{array}$} & \multirow[b]{2}{*}{ Element } & \multirow{2}{*}{$\begin{array}{c}\text { Wave- } \\
\text { length } \\
\text { (nm) }\end{array}$} & \multicolumn{2}{|c|}{$\begin{array}{l}\text { Detection limit } \\
\text { (ppm) }\end{array}$} \\
\hline & & $\begin{array}{l}\text { Present } \\
\text { work }\end{array}$ & $\begin{array}{c}\text { Gokun } \\
(1975)\end{array}$ & & & $\begin{array}{l}\text { Present } \\
\text { work }\end{array}$ & $\begin{array}{l}\text { Gokun } \\
(1975)\end{array}$ \\
\hline $\mathrm{Pb}$ & $283 \cdot 307$ & 0.1 & 100 & $\mathrm{Ga}$ & $294-364$ & 0.3 & 100 \\
\hline Mo & $317 \cdot 035$ & 0.1 & 100 & $\mathbf{B e}$ & $313-042$ & 0.3 & 100 \\
\hline $\mathrm{Cu}$ & 327.396 & $0 \cdot 1$ & 100 & Co & $345 \cdot 351$ & 1 & N.D. \\
\hline $\mathbf{Y b}$ & 328.937 & 0.1 & N.D. & Sc & $424-683$ & 1 & 100 \\
\hline $\mathbf{N i}$ & $341 \cdot 477$ & 0.1 & 100 & V & 437.924 & 1 & 100 \\
\hline $\mathrm{Cr}$ & $425 \cdot 434$ & 0.1 & 100 & $\mathbf{B i}$ & 306.772 & 3 & N.D. \\
\hline $\mathrm{Ba}$ & $455-404$ & 0.1 & 100 & $\mathbf{Y}$ & $332 \cdot 788$ & 3 & 100 \\
\hline Sn & 283.999 & $0 \cdot 3$ & 5 & La & $433 \cdot 347$ & 10 & N.D. \\
\hline
\end{tabular}

N.D. not detected. 
Table 2. Results of analysis of granite rock standard USGS-G $G_{2}$ together with standard deviations (S) and relative deviation (C)

\begin{tabular}{lcccc}
\hline Element & $\begin{array}{c}\text { Flanagan } \\
(1973)\end{array}$ & $\begin{array}{c}\text { Present } \\
\text { work }\end{array}$ & $s$ & $C$ \\
\hline $\mathrm{Be}$ & 2.6 & 3.1 & 0.70 & 24.7 \\
$\mathrm{Ga}$ & 22 & 18 & 1.9 & 11.5 \\
$\mathrm{Cu}$ & 11.7 & 10.27 & 1.58 & 13.8 \\
$\mathrm{Mo}$ & 0.36 & 0.5 & 0.06 & 11.5 \\
Y & 12 & 11.1 & 1.69 & 15.25 \\
Yb & 0.88 & 0.8 & 0.15 & 18.8 \\
$\mathrm{Sn}$ & 1.5 & 1.33 & 0.02 & 1.5 \\
$\mathrm{Cr}$ & 7 & 5.3 & 0.77 & 14.5 \\
$\mathrm{Sc}$ & 3.7 & 3.22 & 0.16 & 5.08 \\
\hline
\end{tabular}

between \pm 1.5 and \pm 24.7 . As shown in table 2 , the present values of trace elements in $G_{2}$, are in good agreement with earlier values (Flanagan 1973). This shows that the accuracy of the method is satisfactory. Moreover the reported relative deviation values in table 2 for all the elements are much better than the value of $25 \%$ given by Gokun (1975).

\section{References}

Ahrens L H and Taylor S R 1961 Spectrochemical analysis (London: Addison-Wesley) 2nd edn Bowmans P W J M 1966 Theory of spectrochemical excitation (London: Hilger Watts) pp 192 El Bialy A, Rasmy M N, Guirguis L A and Moussa W 1984 Bull. Nat. Res. Council (Cairo) (accepted) Flanagan F J 1973 Geochim. Cosmoch. Acta 371189

Fleischer M 1972 Science 1996

Gokun V N 1975 Tr. Akad. Nauk USSR 35105

Mika J and Torok T 1974 Analytical emission spectroscopy Fundamentals (Hung), Eng. Transl. P A Floyd (London: Butterworth)

Peter S 1969 Math. Nakur. Wiss. Reibe 1, 8, 8971

Rasmy M 1983 Bull. Nat. Res. Council (Cairo)

Sighinolf G P 1966 Period Minerel Rome 35, 3769

Watson A F and Russell G U 1978 Spectrochim. Acta part 2, 33, 5173

Wedepohl K H (ed.) 1969 Data of geochemistry (Berlin: Springer) Vol. 1 